\title{
NUTRITIONAL STATUS OF ORANG ASLI CHILDREN IN SUNGAI BERUA, TERENGGANU
}

\author{
SENG KAI YEE, ASMA' ALI, NOOR SALIHAH ZAKARIA, AND HAYATI MOHD YUSOF \\ Faculty of Fisheries and Food Science, Universiti Malaysia Terengganu, 21030 Kuala Nerus, Terengganu, Malaysia.
}

*Corresponding author: hayatimy@umt.edu.my

Submitted final draft: 19 October $2020 \quad$ Accepted: 23 November $2020 \quad$ http://doi.org/10.46754/jssm.2021.08.016

\begin{abstract}
This study aimed to determine the nutritional status of Orang Asli children in Sekolah Kebangsaan (SK) Sungai Berua, Kuala Berang, Terengganu, Malaysia. Participants included 77 school children aged between 7 and 12 years, consisting of 38 boys and 39 girls. The methods used to determine the children's nutritional status included anthropometric measurements, biochemical analysis for hemoglobin and urinalysis, as well as urinary iodine determination. Using World Health Organization (WHO) reference standards, it was found that $32.4 \%$ of the respondents were underweight, $9.9 \%$ severely underweight, $35.2 \%$ stunted, and $40.8 \%$ severely stunted. The Body Mass Index (BMI)-for-age also indicated that $8.5 \%$ of the respondents were "wasted" and $8.5 \%$ were "severely wasted". Overall, the mean hemoglobin of the children was $10.6 \mathrm{~g} / \mathrm{dL}$ and the median of urinary iodine concentration was $131.3 \mu \mathrm{g} / \mathrm{L}$. Iodine deficiency was widespread among Orang Asli children, with $40.3 \%$ of children showing low urinary iodine levels. Hemoglobin had a significant correlation with BMI $(r=0.310, p<0.05)$. The present study shows that underweight, stunting, wasting, anemia and iodine deficiency are still widespread among Orang Asli children. Nutrition and health intervention is needed to reduce these risks.
\end{abstract}

Keywords: Nutritional status, Orang Asli, children, malnutrition.

\section{Introduction}

Undernutritionisalife-threateninghealthproblem found predominantly among communities living in unfavorable conditions, these communities include the Orang Asli. In Malaysia, malnutrition has been prevalent among Orang Asli children for decades, especially in remote areas (United Nations Development Programme [UNDP], 2016). Although the Malaysian government has made efforts to improve their lives, the health of the Orang Asli in Peninsular Malaysia remains poor.

They live predominantly in remote jungles, lowlands and coastal areas and are very dependent on natural resources for sustenance. They have been marked as the poorest of the poor, and their household income is far below the baseline indicated by the United Nations Millennium Development Goals 2015 (UNDP, 2016). Poverty is the leading factor of malnourishment contributing to child mortality (WHO, 2016) and in accordance with that report, one of United Nations Millennium Development Goal set in 2015 was the reduction of child mortality (UNDP, 2016). As reported by World Health Organization (WHO, 2016), 5.9 million children under the age of five years died in 2015, this represents nearly 16,000 deaths daily. Over one-third of child mortality cases that occur in low-income countries is caused by malnutrition. Poor nutrition not only influences cognitive development (Frisvold, 2015; Zhang et al., 2010) and the immune system (Marques et al., 2013), but also indirectly leads to emotional and psychological problems (Walker et al., 2007). Malnourished children are often susceptible to problems such as iron deficiency anemia,being severely underweight, stunting, wasting, iodine deficiency and infection (Eze et al., 2017). Recently, a study reported that some socio-demographic factors including father's educational and income, hemoglobin status, infections and environment are responsible in affecting Orang Asli's children cognitive performance (Murtaza et al., 2019). 
The Orang Asli around Kenyir Lake, a well-known tourist spot in Terengganu, Malaysia were moved to an Orang Asli resettlement area near the lake called Kampung Sungai Berua. Kampung Sungai Berua is located about $32 \mathrm{~km}$ from Pengkalan Gawi and 9km from Sungai Como (Jabatan Kemajuan Orang Asli [JAKAO], 2015). This Orang Asli resettlement area was established by Jabatan Hal Ehwal Orang Asli (JHEOA) in 1977. Sekolah Kebangsaan Sungai Berua is the primary school located in the village. The residents of the village were moved from the National Park around Kenyir Lake a few decades ago. The displacement of Orang Asli is considered beneficial to the community, as it improved their economy, access to education, and overall lifestyle (Zahari et al., 2014).

Few studies have been conducted among Orang Asli children as compared with children of other ethnicities. Previous research on the nutritional status of the Orang Asli was carried out in Kelantan, Perak, Selangor, and Pahang (Mian \& Leng, 1998; Zulkifli et al., 1999; Yusof et al., 2007; Haemamalar et al., 2010). These studies varied broadly in terms of their emphasis, encompassing everything from malnutrition, malaria, filariasis and microbial infections. Some of these studies focused on food security (Nurfahilin \& Norhasmah, 2015; Wong et al., 2015) and micronutrients (Osman, 2000; Ismail et al., 2009). Several studies have also drawn attention to soil-transmitted helminthiasis among Orang Asli children (Ngui et al., 2012; Al-Delaimy et al., 2014).

Studies have also found infections associated with malnutrition, especially stunting and wasting. Many studies have shown that being underweight and being stunted are widespread among Orang Asli children in Malaysia (Lin,
1988; Zalilah \& Tham, 2002; Aini et al., 2007). Nevertheless, to date, no study have been carried out to assess the nutritional status of Orang Asli children in Terengganu.

Therefore, the present study aims to determine nutritional status by anthropometric measurements and biochemical assessments among Orang Asli children at SK Sungai Berua, as well as identify the interrelationship between anthropometric measurements, hemoglobin concentration, urinalysis, and urinary iodine concentration.

\section{Materials and Methods}

A cross-sectional study was conducted in SK Sungai Berua. There are three Orang Asli settlements in the state of Terengganu: Sungai Berua, Hulu Terengganu; Sungai Pergam, Kemaman and Sungai Sayap, Besut (Jabatan Kemajuan Orang Asli [JAKOA], 2015). Hulu Terengganu is a rural area in Terengganu. This area became more populated after the building of a hydroelectric dam on Kenyir Lake. For this study, the Kampung Sungai Berua which is located $5 \mathrm{~km}$ from Kenyir Lake was selected as the study location, as this is the only Orang Asli resettlement area in Hulu Terengganu. There are two main Orang Asli ethnicities in the village: the Semoq Beri and Batek. The Orang Asli children study at SK Sungai Berua, a primary school located in Kampung Sungai Berua. Based on records at the school, 96 school-aged children are currently studying at SK Sungai Berua (Mohd Noor, 2016).

Thus, the school was the locus for the collection of data. Figure 1 shows the location of the study. 


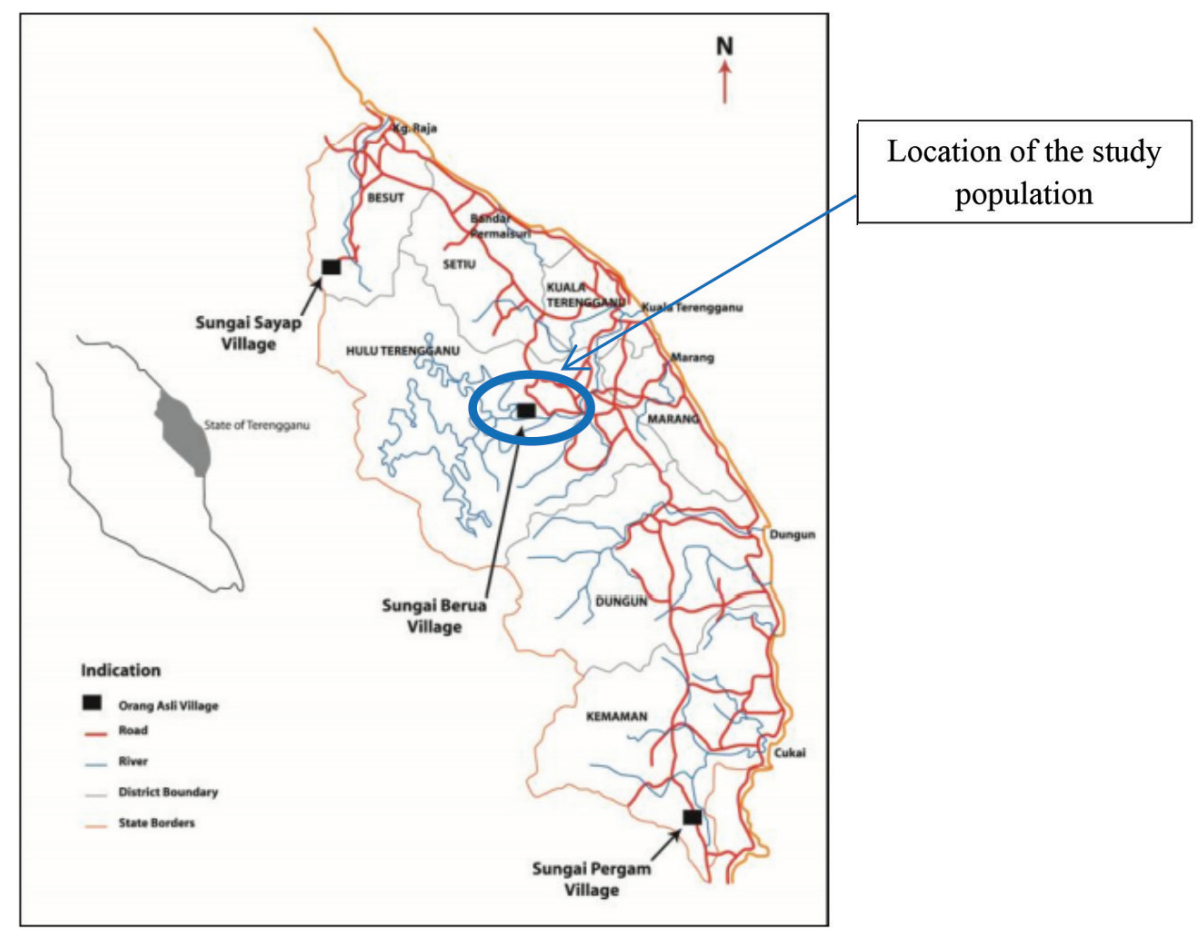

\section{Subjects}

Initially, all students aged between 7 and 12 years from SK Sungai Berua were invited to participate in this study on a voluntary participation basis.

Using the standard formula, a sample size of 77 respondents was required for a $95 \%$ confidence interval and a margin of error of $5 \%$.

Sample size $=\frac{\frac{z^{2} \times p(1-p)}{e^{2}}}{1+\left(\frac{z^{2} \times p(1-p)}{e^{2} N}\right)} ;$

where $\mathrm{N}=$ population size

$$
\begin{aligned}
& \mathrm{z}=\mathrm{z} \text {-score } \\
& \mathrm{e}=\text { margin of error } \\
& \mathrm{p}=\text { standard deviation }
\end{aligned}
$$

$$
\begin{aligned}
\text { Sample size } & =\frac{\frac{1.96^{2} \times 0.5(1-0.5)}{0.05^{2}}}{1+\left(\frac{1.96^{2} \times 0.5(1-0.5)}{0.05^{2}(96)}\right)} \\
& =76.83 \approx 77
\end{aligned}
$$

\section{Anthropometric Measurements}

Body weight and body fat were measured without shoes and socks using a Tanita digital body fat scale UM-02 (Tanita, UK) to the nearest $0.1 \mathrm{~kg}$. Height was taken to the nearest $0.1 \mathrm{~cm}$ by the SECA stadiometer. BMI was calculated using weight and height. The collected anthropometric data was further classified using WHO growth references for children between 5 and 19 years of age. WHO AnthroPlus version 1.0.3 software was utilised to determine the z-scores for height-for-age and BMI-for-age. This score was further used to classify children as normal, stunted; underweight, normal and overweight, respectively.

\section{Biochemical Assessments}

Hemoglobin concentration was measured using finger prick test and analyzed on the spot using HemoCue ${ }^{\circledR} 201$ a handheld hemoglobin photometer. Urinalysis was performed using a portable urine analyzer. Urine was collected using a specimen cup. The urine test strip (AKRKAY AUTION Sticks 10 EA) was dipped 
into the urine and placed into the urine analyzer. Urine Analyzer PocketChem TM UA PU-4010 was used to determine the presence of red blood cells, glucose, protein, ketones, bilirubin, and the $\mathrm{pH}$ of urine. For urinary iodine analysis, the modified micro method was used to evaluate the concentration of urinary iodine based on Sandell-Kolthoff reaction.

\section{Statistical Analysis}

Data were analyzed using Statistical Package for the Social Sciences (SPSS, version 20.0) for Windows. Student's t-test and Mann-Whitney U-test were used to compare the outcomes between genders. Spearman's correlation tests were used to determine the relationship between anthropometric measurements and biochemical assessments. In all analysis, the significance level was set at $\mathrm{p}<0.05$.

\section{Results}

\section{Demographic Characteristics}

Seventy-seven students ( 38 boys and 39 girls) aged between 7 and 12 years participated in this study. All of the respondents in this study were from Batek tribe. Table 1 shows the demographic characteristics of the respondents.

\section{Anthropometry}

The anthropometric measurements of the respondents are shown in Table 2. The mean height and weight were $125.8 \mathrm{~cm}$ and $23.1 \mathrm{~kg}$, respectively. The mean height of girls was higher than boys $(\mathrm{t}=-0.209, \mathrm{p}<0.05)$ perhaps because more girls $(n=21)$ than boys $(n=12)$ aged between 10 and 12 years joined the study. The mean BMI of children was $14.3 \mathrm{~kg} / \mathrm{m}^{2}$, falling within the normal range. The mean body fat of respondents was $11.3 \pm 4.0 \%$, indicating that the majority of the respondents were underfat. There were no significant differences in weight, BMI and body fat between boys and girls.

Based on the WHO reference standard, the present study found that $32.4 \%$ of the children were underweight, $9.9 \%$ severely underweight, $35.2 \%$ stunted and $40.8 \%$ severely stunted. Furthermore, their BMI-for-age also demonstrated that $8.5 \%$ of the respondents were wasted and or severely wasted

\section{Risk of anemia}

Table 3 indicates the risk of anemia among children. The overall hemoglobin concentration for children was only $10.6 \mathrm{~g} / \mathrm{dL}$, in the range of 5.7 to $14.9 \mathrm{~g} / \mathrm{dL}$, with median $10.9 \mathrm{~g} / \mathrm{dL}$ for boys and mean $10.7 \mathrm{~g} / \mathrm{dL}$ for girls, respectively. Most of the children $(>60 \%)$ suffered from moderate anemia $(8.0-10.9 \mathrm{~g} / \mathrm{dL})$.

Table 1: Demographic characteristics of the respondents

\begin{tabular}{ccc}
\hline Indicators & $\begin{array}{c}\text { Frequency } \\
(\mathbf{n}=\mathbf{7 7})\end{array}$ & $\begin{array}{c}\text { Percentage } \\
\mathbf{( \% )}\end{array}$ \\
\hline Gender & & \\
Boys & 38 & 49.5 \\
Girls & 39 & 50.6 \\
Age (years) & & \\
7 & 12 & 15.6 \\
8 & 12 & 15.6 \\
9 & 19 & 24.7 \\
10 & 17 & 22.1 \\
11 & 5 & 6.5 \\
12 & 12 & 15.6 \\
Race & & \\
Batek & 77 & 100 \\
\hline
\end{tabular}


Table 2: Anthropometric measurements and body weight of the respondents

\begin{tabular}{|c|c|c|c|c|c|c|c|c|}
\hline \multirow[t]{2}{*}{ Parameter } & \multicolumn{2}{|c|}{ Overall } & \multicolumn{2}{|c|}{$\begin{array}{c}\text { Boys } \\
(n=\mathbf{3 8}) \\
\end{array}$} & \multicolumn{2}{|c|}{$\begin{array}{c}\text { Girls } \\
(n=39)\end{array}$} & \multirow[t]{2}{*}{$\begin{array}{c}\text { t-value/ } \\
\text { z-value }\end{array}$} & \multirow[t]{2}{*}{$P$ value } \\
\hline & $\begin{array}{l}\text { Mean / } \\
\text { Median } \\
\end{array}$ & Range & $\begin{array}{c}\text { Mean / } \\
\text { Median }\end{array}$ & Range & $\begin{array}{l}\text { Mean / } \\
\text { Median } \\
\end{array}$ & Range & & \\
\hline $\begin{array}{l}\text { Height } \\
(\mathrm{cm})\end{array}$ & $\begin{array}{c}125.76 \pm \\
9.89\end{array}$ & $\begin{array}{c}101.50- \\
148.50\end{array}$ & $\begin{array}{l}123.43 \\
\pm 8.94\end{array}$ & $\begin{array}{c}101.50- \\
143.50\end{array}$ & $\begin{array}{c}128.03 \pm \\
10.35\end{array}$ & $\begin{array}{c}110.20- \\
148.50\end{array}$ & $\begin{array}{c}\mathrm{t}= \\
-2.09\end{array}$ & $0.04 *$ \\
\hline Weight (kg) & $\begin{array}{c}23.12 \pm \\
6.64\end{array}$ & $\begin{array}{c}12.60- \\
45.00\end{array}$ & $\begin{array}{l}21.40 \\
(6.00)\end{array}$ & $\begin{array}{c}12.60- \\
38.80\end{array}$ & $\begin{array}{l}21.40 \\
(7.40)\end{array}$ & $\begin{array}{c}15.50- \\
45.00\end{array}$ & $\begin{array}{c}z= \\
-1.08\end{array}$ & 0.280 \\
\hline $\begin{array}{l}\text { BMI }(\mathrm{kg} / \\
\left.\mathrm{m}^{2}\right)\end{array}$ & $\begin{array}{c}14.32 \pm \\
2.01\end{array}$ & $\begin{array}{l}10.91- \\
21.45\end{array}$ & $\begin{array}{l}13.83 \\
(1.73)\end{array}$ & $\begin{array}{l}10.91- \\
21.45\end{array}$ & $\begin{array}{l}13.73 \\
(2.68)\end{array}$ & $\begin{array}{l}11.68- \\
20.41\end{array}$ & $\begin{array}{c}z= \\
-0.392\end{array}$ & 0.695 \\
\hline $\begin{array}{l}\text { Body fat } \\
(\%)\end{array}$ & $\begin{array}{c}11.30 \pm \\
4.03\end{array}$ & $\begin{array}{l}5.90- \\
24.10\end{array}$ & $\begin{array}{c}10.59 \pm \\
3.57\end{array}$ & $\begin{array}{l}7.70- \\
22.70\end{array}$ & $\begin{array}{l}10.80 \\
(7.10)\end{array}$ & $\begin{array}{l}5.90- \\
24.10\end{array}$ & $\begin{array}{c}z= \\
-1.075\end{array}$ & 0.282 \\
\hline $\begin{array}{c}\text { Ht-for-age } \\
\text { Normal } \\
\text { Stunted }\end{array}$ & & $\begin{array}{r}\text { Over } \\
48 \\
29\end{array}$ & $\begin{array}{l}\text { ll, n (\%) } \\
(62.3) \\
(37.7)\end{array}$ & & $\begin{array}{c}\text { Boys, n (\%) } \\
24(63.2) \\
14(38.8)\end{array}$ & & $\begin{array}{c}\text { Girls, n } \\
24(61 . \\
15\end{array}$ & \\
\hline \multicolumn{9}{|l|}{ BMI-for-age } \\
\hline \multicolumn{2}{|l|}{ Underweight } & \multicolumn{2}{|c|}{$37(48.1)$} & \multicolumn{3}{|c|}{$17(44.7)$} & \multicolumn{2}{|c|}{$20(51.3)$} \\
\hline \multicolumn{2}{|l|}{ Normal } & \multicolumn{2}{|c|}{$39(50.6)$} & \multicolumn{2}{|r|}{$20(52.7)$} & & \multicolumn{2}{|c|}{19 (48.7) } \\
\hline \multicolumn{2}{|l|}{ Overweight } & \multicolumn{2}{|c|}{$1(1.3)$} & \multicolumn{2}{|r|}{$1(2.6)$} & & \multicolumn{2}{|c|}{-} \\
\hline
\end{tabular}

Data are presented as mean $\pm \mathrm{SD}$ or as median (IQR); * significantly difference between genders by Independent t-test

Table 3: Risk of anemia among the respondents

\begin{tabular}{cccc}
\hline Indicators & $\begin{array}{c}\text { Number } \\
(\mathbf{n})\end{array}$ & $\begin{array}{c}\text { Hemoglobin } \\
\text { concentration } \\
\mathbf{( g / d L )}\end{array}$ & $\begin{array}{c}\text { Range } \\
(\mathbf{g} / \mathbf{d L})\end{array}$ \\
\hline Overall & $(\mathrm{n}=73)$ & $10.60 \pm 1.93$ & $5.70-14.90$ \\
Normal & 28 & 38.4 & \\
Anemic & 45 & 61.6 & \\
\hline Boys & $(\mathrm{n}=37)$ & $10.90(2.30)$ & $5.70-13.70$ \\
Normal & 15 & 40.5 & \\
Anemic & 22 & 59.5 & \\
\hline Girls & $(\mathrm{n}=36)$ & $10.66 \pm 1.88$ & $6.50-14.90$ \\
Normal & 13 & 36.1 & \\
Anemic & 23 & 63.9 & \\
\hline
\end{tabular}

Data are presented as mean $\pm \mathrm{SD} /$ median (IQR).

\section{Urinalysis}

Urinalysis of children is described in Table 4. The findings revealed that $55.6 \%$ had hematuria and $37.5 \%$ had abnormal leukocyte esterase. The median $\mathrm{pH}$ of urine was 5.5 , while the median urinary specific gravity was 1.020 . The overall results of urinalysis showed that the prevalence risk of infection was high in Orang
Asli children. A majority of the children showed positive leukocyte esterase and blood in the urine.

\section{Urinary Iodine}

The overall mean urinary iodine concentration of children was $131.32 \mu \mathrm{g} / \mathrm{L}$, which falls within the normal range. This means that many of the 
children in the study have an adequate iodine intake. Mann-Whitney U-test shows that there was no significant difference between genders. Based on the urinary iodine classification of less than $100 \mathrm{ug} / \mathrm{L}$ to indicate insufficient iodine intake (De Benoist et al., 2004), the present study found that $40.3 \%$ of respondents $(n=29)$ suffered from iodine deficiency. Table 5 shows the urinary iodine concentration of the respondents between genders and its category.

\section{Discussion}

There were no significant differences in weight, BMI, and body fat between boys and girls.
However, there is a significant difference between the heights of boys and girls ( $\mathrm{t}=$ $-0.29, \mathrm{p}<0.05)$. Boys and girls showed similar weights, which is in accordance to Bong et al. (2012) that only as they grow older into puberty do boys tend to be taller and heavier than girls. A majority of Orang Asli children do not follow normal growth patterns as shown in WHO growth charts as compared to children in the United States, Ghana, India, Norway, Brazil, and Oman, as indicated by Onis et al. (2007). The growth patterns of children may greatly differ. Generally, children experience physical growth during childhood, and weight and height changes rapidly (Ceelen et al., 2009).

Table 4: Results of urinalysis

\begin{tabular}{|c|c|c|c|c|c|c|}
\hline \multirow[t]{2}{*}{ Parameter } & \multicolumn{2}{|r|}{ Overall } & \multicolumn{2}{|c|}{ Boys } & \multicolumn{2}{|c|}{ Girls } \\
\hline & $\begin{array}{c}\text { Number } \\
\text { (n) }\end{array}$ & $\begin{array}{c}\text { Percentage } \\
(\%)\end{array}$ & $\begin{array}{c}\text { Number } \\
\text { (n) }\end{array}$ & $\begin{array}{c}\text { Percentage } \\
(\%)\end{array}$ & $\begin{array}{c}\text { Number } \\
\text { (n) }\end{array}$ & $\begin{array}{c}\text { Percentage } \\
(\%)\end{array}$ \\
\hline \multicolumn{7}{|l|}{ Glucose } \\
\hline Normal & 71 & 98.6 & 36 & 100.0 & 35 & 97.2 \\
\hline Abnormal & 1 & 1.4 & 0 & 0.0 & 1 & 2.8 \\
\hline \multicolumn{7}{|l|}{ Ketone } \\
\hline Normal & 70 & 97.2 & 34 & 94.4 & 36 & 100.0 \\
\hline Abnormal & 2 & 2.8 & 2 & 5.6 & 0 & 0.0 \\
\hline \multicolumn{7}{|l|}{ Blood } \\
\hline Normal & 40 & 55.6 & 21 & 58.3 & 19 & 52.8 \\
\hline Abnormal & 32 & 44.4 & 15 & 41.7 & 17 & 47.2 \\
\hline \multicolumn{7}{|l|}{ Protein } \\
\hline Normal & 72 & 100.0 & 36 & 100.0 & 36 & 100.0 \\
\hline Abnormal & 0 & 0.0 & 0 & 0.0 & 0 & 0.0 \\
\hline \multicolumn{7}{|l|}{ Leukocyte } \\
\hline Normal & 45 & 62.5 & 27 & 75.0 & 18 & 50.0 \\
\hline Abnormal & 27 & 37.5 & 9 & 25.0 & 18 & 50.0 \\
\hline \multicolumn{7}{|l|}{ Bilirubin } \\
\hline Normal & 69 & 95.8 & 35 & 97.2 & 34 & 94.4 \\
\hline Abnormal & 3 & 4.2 & 1 & 2.8 & 2 & 5.6 \\
\hline \multicolumn{7}{|l|}{ Urobilinogen } \\
\hline Normal & 63 & 87.5 & 32 & 88.9 & 31 & 86.1 \\
\hline Abnormal & 9 & 12.5 & 4 & 11.1 & 5 & 13.9 \\
\hline \multicolumn{7}{|l|}{ Nitrite } \\
\hline Normal & 71 & 98.6 & 36 & 100.0 & 35 & 97.2 \\
\hline Abnormal & 1 & 1.4 & 0 & 0.0 & 1 & 2.8 \\
\hline $\mathrm{pH}$ & \multicolumn{2}{|c|}{$5.50(0.50)$} & \multicolumn{2}{|c|}{$5.5(0.00)$} & \multicolumn{2}{|c|}{$5.50(0.50)$} \\
\hline Specific gravity & \multicolumn{2}{|c|}{$1.020(0.10)$} & \multicolumn{2}{|c|}{$1.020(0.009)$} & \multicolumn{2}{|c|}{$1.020(0.10)$} \\
\hline
\end{tabular}


Table 5: Urinary iodine concentration of the respondents

\begin{tabular}{lccc}
\hline \multicolumn{1}{c}{ Gender } & Number $(\mathbf{n})$ & $\begin{array}{c}\text { Urinary Iodine } \\
\text { Concentration }(\boldsymbol{\mu g} / \mathbf{L})\end{array}$ & Range $(\boldsymbol{\mu g} / \mathbf{L})$ \\
\hline Overall & 72 & $131.32(63.03)$ & $8-328$ \\
Boys & 36 & $127.69 \pm 69.74$ & $8-328$ \\
Girls & 36 & $134.94(56.29)$ & $55-316$ \\
Urinary iodine & Number (n) & Iodine intake status & Iodine status \\
(ug/L) & 1 & Insufficient & Severe iodine deficiency \\
$<20$ & 2 & Insufficient & Moderate iodine deficiency \\
$20-49$ & 26 & Insufficient & Mild iodine deficiency \\
$50-99$ & 34 & Adequate requirement & Adequate iodine \\
$100-199$ & 7 & Above requirement & At risk of iodine induced-hyperthyrodism \\
$200-299$ & 2 & Excessive & Risk of adverse health consequences \\
$>300$ & & &
\end{tabular}

Overall, the mean BMI for both genders among the children in the study were categorised as normal. The way the BMI is interpreted is age and gender specific for children as the amount of body fat changes with age and varies with gender as the child grows (Chung, 2015). Thus, the calculated BMI values were further analysed using a BMI-for-age percentile chart.

These findings show that malnutrition persists among Orang Asli children aged between 7 and 12 years. The prevalence of underweight and stunted children is high. The nutritional status of Orang Asli children has remained poor since the 1980 's. Some of the present findings are similar to trends in other locations in Malaysia, as being underweight and stunted remains widespread in certain areas among Orang Asli children (Lin, 1988; Zalilah et al., 2002; Aini et al., 2007; Yusof et al., 2007; Zainuddin et al., 2013).

The present findings are consistent with an earlier study among Semai Orang Asli school children in Perak. Almost 30 years ago, it was found that $51 \%$ boys and $46 \%$ of girls were underweight. Stunting was found in $71 \%$ of boys and 65\% of girls (Lin, 1988).

Comparatively, the present findings describe more cases of underweight and stunting among boys over girls. This may be because boys are more likely to be affected by environmental stress than girls, resulting in stunted growth (Olack et al., 2011).

Wong et al. (2016) documented that more than $50 \%$ of Orang Asli children in Pos Legap, Perak were underweight and over $30 \%$ of children still stunted. Furthermore, it was reported that the poor nutritional status of Orang Asli children was probably due to a soil-transmitted helminth (STH) infection, since the majority of children were infected. However, stool examinations were not conducted in the present study; as a result, infection cannot be ruled out as one of the predicted factors of malnutrition in Orang Asli children in SK Sungai Berua.

More girls than boys were classed as "underweight" as shown in Table 2. This may be explained by gender disparities in Orang Asli families. Girls may suffer from unequal access to quality food (Ramchandran, 2014). In addition, different childcare practices with reference to boys and girls in the family might also be a reason behind differing nutritional outcomes (Vlassoff, 2007). Poor nutritional status among Orang Asli children was shown since the percentage of underweight and stunting for both genders remain high (approximately between $40 \%$ and $50 \%$ ) over the last three decades (Lin et al., 1988; Zulkifli et al., 1999; Shariff et al., 2000; Al-Mekhlafi et al., 2008; Wong et al., 2016). 
Additionally, Shariff et al. (2000) revealed that regardless of ethnicity or location, rates of underweight in boys and girls were around $55 \%$ and $49 \%$, respectively. Furthermore, their study reported that $50 \%$ of boys and $47 \%$ girls experience stunting. Rates of malnutrition were almost similar to the present findings that $51 \%$ of girls and $45 \%$ of boys were underweight, and $38.8 \%$ of boys and $38.5 \%$ of girls were stunted. However, in that study more Orang Asli boys were stunted as compared to the present study.

Again, regardless of ethnicity and study location, the nutritional statuses of children in Kuala Lumpur and the present study are similar. Thus, it is suggested that one of the factors contributing to malnutrition in children is the socio-economic status of the household, rather than ethnicity.

Widespread malnutrition among Orang Asli children might be influenced by inadequacy of energy intake to support growth and development. It is well known that unavailability of fresh food leads to inadequate nutrient and energy intake for children who live in rural areas (Pollard et al., 2014). The distance between Kampung Sungai Berua to the nearest town is around $20 \mathrm{~km}$, but due to the lack of a public transportation system, most residents rarely travel to town in order to obtain fresh food, as they do not have their own vehicles. The poor health status of Orang Asli children might also be related to infection.

An earlier study by Norhayati et al. (1997) among Orang Asli children reported a high prevalence of infection including Trichuasis (63\%), Ascariasis (92\%) and hookworm $(30 \%)$, though decreases were found in overall prevalence rates in Malaysia. Recently, a study of Orang Asli children in Negeri Sembilan reported that $35 \%$ had parasitic infections with $58 \%$ infected with Trichuris trichiuria, 11\% with Ascaris lumbricoides and $36 \%$ by both parasites (Murtaza et al., 2019).

In terms of biochemical assessment, the mean hemoglobin concentration for Orang Asli children in the present study is low as compared to previous studies (Aini et al.,
2007; Al-Mekhlafi et al., 2008; Ahmed et al., 2012). Generally, anemia among children is caused by insufficient intake of iron, folate, and vitamin B-12 in the diet (WHO, 2015). In the present study, there were more anemic Orang Asli children at younger ages, which may be because the overall nutrition of children was not met. Anemia cases among Orang Asli might also be high due to parasitic infections, hemoglobinopathies, and a lack of sufficient dietary iron. Thus, Orang Asli children are most susceptible to being underweight, stunted and suffering from anemia.

The varying prevalence of anemia in different study locations is likely due to the inaccessibility to food. As indicated by WHO (2001), the meal pattern of Southeast Asians is low in protein and iron. A poor iron intake, together with poverty and infections, could be a contributing factor of anemia and iron deficiency anemia (IDD) among children in remote areas. Apart from that, Aini et al. (2007) found that the severe trichurisiasis was significantly associated with anemia.

Previous studies also identified hookworm infection as a strong predictor of IDA and low socioeconomic status, also influencing dietary iron intake among children (Ngui et al., 2012).

As indicated by the urinalysis results, the present study suggested a high risk of infection among the children. Infection might be a consequence of practices such as drinking nonboiled water. Soil-transmitted helminths might occur because most Orang Asli children remain barefoot at home, with some also not wearing shoes during school time.

Thus, poor nutritional status of Orang Asli children may be caused by soil-transmitted helminth infection, as reported in several previous studies (Ahmed et al., 2012; AlMekhlafi et al., 2013; Al-Delaimy et al., 2014; Wong et al., 2016).

Interestingly, Orang Asli children in the present study have slightly higher urinary iodine concentrations than most other locations in Malaysia except Sabah (Selamat et al., 2010). 
This might be due to the availability of iodine rich food sources from fresh fish in Banding Lake, since the most important reservoir of iodine is in the soil that runs into the lake's water. It is thus easier for children to get iodine rich foods, resulting in higher frequency of iodine food consumption and lowering the risk of iodine deficiency.

In the present study, Spearman's correlation tests indicate a weak relationship between hemoglobin with BMI $(r=0.310, p=0.008)$. A preliminary study in Japan also reported a positive association between hemoglobin levels and BMI (Shimizu et al., 2014). Individuals with abnormal BMI might have a higher risk of iron deficiency anemia and iron deficiency than individuals with desirable BMI (Keikhaei et al., 2012). This is because hemoglobin concentration increases with BMI as children get sufficient nutrition for growth and build more hemoglobin. Thurlow (2006) supported the present findings, as no association was observed between urinary iodine levels and biochemical iron indices among school children in Thailand. Thus, hemoglobin concentrations might not affect urinary iodine concentration. Furthermore, the present findings show no significant relationship between body fat and hemoglobin concentration. In contrast, Moschonis et al. (2012) revealed that the percentage of body fat and visceral fat mass were positively associated with iron deficiency in schoolchildren in Greece. The variation of results might be due to that there was no obese child found in the Orang Asli population and most children were underweight.

\section{Conclusion}

The overall nutritional status of Orang Asli children in SK Sungai Berua was found to be poor. The poor nutritional status of Orang Asli children might be influenced by their poor socio-economic status, environmental factors, and infections which all affect their nutrient intakes, immunity, and health status. Although the government has gradually improved the socioeconomic status, educational standards and health facilities in the Orang Asli settlements, much more can still be done. If children are given a more conducive environment, they might experience better growth.

\section{Acknowledgements}

Authors) would like to express our gratitude to Professor Calder PC for critical comments on the manuscript. Special thanks to Head Master and teachers in Sekolah Kebangsaan Berua and Jabatan Hal Ehwal Orang Asli, Terengganu. This research has been funded by the School of Food Science and Technology, Universiti Malaysia Terengganu.

\section{References}

Ahmed, A., Al-Mekhlafi, H. M., Al-Adhroey, A. H., Ithoi, I., Abdulsalam, A. M., \& Surin, J. (2012). The nutritional impacts of soil-transmitted helminths infections among Orang Asli school children in rural Malaysia. Parasites and Vectors, 15(5), 119.

Aini, U. N., Al-Mekhlafi, M. H., Azlin, M., Shaik, A., Sa, A., Fatimah, M. S., Ismail, M. G., Firdaus, M. A., Aisah, M. Y., Rozlida, A. R., \& Norhayati, M. (2007). Serum iron status in Orang Asli children living in endemic areas of soil-transmitted helminths. Asia Pacific Journal of Clinical Nutrition, 16, 724-30.

Al-Delaimy, A. K., Al-Mekhlafi, H. M., Nasr, N. A., Sady, H., Atroosh, W. M., Nashiry, M., Anuar, T. S., Moktar, N., Lim, Y. A., \& Mahmud, R. (2014). Epidemiology of intestinal polyparasitism among Orang Asli school children in rural Malaysia. PLoS Neglected Tropical Diseases, 8, e3074.

Al-Mekhlafi, H. M., Al-Maktari, M. T., Jani, R., Ahmed, A., Anuar, T. S., Moktar, N., Mahdy, M. A., Lim, Y. A., Mahmud, R., \& Surin, J. (2013). Burden of Giardia duodenalis infection and its adverse effects on growth of schoolchildren in rural Malaysia. PLoS Neglected Tropical Diseases, 7, e2516. 
De Benoist, B., Andersson, M., Egli, I., Takkouche, B., \& Allen, H. (2004). Iodine statusworldwide. WHO Global Database on Iodine Deficiency. Geneva: World Health Organization, 83, 518-525.

Eze, J. N., Oguonu, T., Ojinnaka, N. C., \& Ibe, B. C. (2017). Physical growth and nutritional status assessment of school children in Enugu, Nigeria. Nigerian Journal of Clinical Practice, 20, 64-70.

Frisvold, D. E. (2015). Nutrition and cognitive achievement: An evaluation of the school breakfast program. Journal of Public Economics, 124, 91-104.

Hussain, H., \& Mohamud, W. N. (2006). A cost-effective modified micromethod for measuring urine iodine. Tropical Biomedicine, 23, 109-115.

Keikhaei, B., Askari, R., \& Aminzadeh, M. (2012). Adolescent with unfeasible Body Mass Index: A risk factor for iron deficiency anemia. Journal of Health and Medical Information, 3, 100109.

Khor, G. K., \& Zalilah, M. S. (2008). The ecology of health and nutrition of Orang Asli (Indigenous people) women and children in Peninsular Malaysia. Tribes and Tribals, 2, 66-77.

Lin, K. G. (1988). Malnutrition among Semai children. Medical Journal of Malaysia, 43, 318-326.

Marques, A. H., O'Connor, T. G., Roth, C., Susser, E., \& Bjørke-Monsen, A. L. (2013). The influence of maternal prenatal and early childhood nutrition and maternal prenatal stress on offspring immune system development and neurodevelopmental disorders. Frontiers in Neuroscience, 7, 120.

Moschonis, G., Chrousos, G. P., Lionis, C., Mougios, V., \& Manios, Y. (2012). Association of total body and visceral fat mass with iron deficiency in preadolescents: The Healthy Growth Study. British Journal of Nutrition, 108, 710-719.
Murtaza, S. F., Gan, W. Y., Sulaiman, N., Mohd Shariff, Z., \& Ismail, S. I. F. (2019). Sociodemographic, nutritional, and environmental factors are associated with cognitive performance among Orang Asli children in Malaysia. PLoS ONE, 14(7), e0219841.

Ngui, R., Lim, Y. A., Kin, L. C., Chuen, C. S., \& Jaffar, S. (2012). Association between anaemia, iron deficiency anaemia, neglected parasitic infections and socioeconomic factors in rural children of West Malaysia. PLoS Neglected Tropical Diseases, 6, e1550.

Olack, B., Burke, H., Cosmas, L., Bamrah, S., Dooling, K., Feikin, D. R., Talley, L. E., \& Breiman, R. F. (2011). Nutritional status of under-five children living in an informal urban settlement in Nairobi, Kenya. Journal of Health, Population and Nutrition, 29, 357-363.

Onis, M. D., Onyango, A. W., Borghi, E., Siyam, A., Nishida, C., \& Siekmann, J. (2007). Development of a WHO growth reference for school-aged children and adolescents. Bulletin of the World Health Organization, 85, 660-667.

Saibul, N., Shariff, Z. M., Lin, K. G., Kandiah, M., Ghani, N. A., \& Rahman, H. A. (2009). Food variety score is associated with dual burden of malnutrition in Orang Asli (Malaysian indigenous peoples) households: Implications for health promotion. Asia Pacific Journal of Clinical Nutrition, 18, 412-422.

Selamat, R., Mohamud, W. N., Zainuddin, A. A., Rahim, N. S., Ghaffar, S. A., \& Aris, T. (2010). Iodine deficiency status and iodised salt consumption in Malaysia: Findings from a national iodine deficiency disorders survey. Asia Pacific Journal of Clinical Nutrition, 19, 578-585.

Shariff, Z. M., Bond, J. T., \& Johson, N. E. (2000). Nutritional status of primary school children from low-income households 
in Kuala Lumpur. Malaysian Journal of Nutrition, 6, 17-32.

Shimizu, Y., Nakazato, M., Sekita, T., Kadota, K., Arima, K., Yamasaki, H., Takamura, N., Aoyagi, K., \& Maeda, T. (2014). Association between the haemoglobin levels and hypertension in relation to the BMI status in a rural Japanese population: The Nagasaki Islands Study. Internal Medicine, 53, 435-40.

Thurlow, R. A., Winichagoon, P., Pongcharoen, T., Gowachirapant, S., Boonpraderm, A., Manger, M. S., Bailey, K. B., Wasantwisut, E., \& Gibson, R. S. (2006). Risk of zinc, iodine and other micronutrient deficiencies among school children in North-East Thailand. European Journal of Clinical Nutrition, 623-632.

Walker, S. P., Chang, S. M., Powell, C. A., Simonoff, E., \& Grantham-McGregor, S. M. (2007). Early childhood stunting is associated with poor psychological functioning in late adolescence and effects are reduced by psychosocial stimulation. The Journal of Nutrition, 137, 2464-2469.

Wong, W. K., Foo, P. C., Roze, M. N., Pim, C. D., Subramaniam, P., \& Lim, B. H. (2016). Helminthic infection and nutritional studies among orang asli children in Sekolah Kebangsaan Pos Legap, Perak. Canadian
Journal of Infectious Diseases and Medical Microbiology, 1326085.

Yusof, H. M., Ching, T. S., Ibrahim, R., \& Lola, S. (2007). Anthropometric indices and life style practices of the indigenous Orang Asli adults in Lembah Belum, Grik of Peninsular Malaysia. Asia Pacific Journal of Clinical Nutrition, 16(1), 49-55.

Zainuddin, A. A., Selamat, R., Baharudin, A., Ghaffar, S. A., Rahim, N. C., \& Aris, T. (2008).Nutritional status of Malaysian primary school children aged $8-10$ years: Findings from the 2008 National IDD Survey. Malaysian Journal of Nutrition, 192, 149-161.

Zalilah, M. S., \& Tham, B. L. (2002). Food security and child nutritional status among Orang Asli (Temuan) households in Hulu Langat, Selangor. Medical Journal of Malaysia, 57, 36-50.

Zhang, Z., Gu, D., \& Hayward, M. D. (2010). Childhood nutritional deprivation and cognitive impairment among older Chinese people. Social Science and Medicine, 71, 941-949.

Zimmermann, M. B. (2006). The influence of iron status on iodine utilization and thyroid function. Annual Review of Nutrition, 26, 367-389. 